\title{
Regulations in Scheduled Intercity Coach Transport Sector in Turkey
}

\author{
Ali Osman Solak ${ }^{1}$ \\ ${ }^{1}$ Faculty of Economic and Administrative Sciences, Abant İzzet Baysal University, Bolu, Turkey \\ Correspondence: Ali Osman Solak, Faculty of Economic and Administrative Sciences, Abant İzzet Baysal \\ University, Bolu, Turkey. Tel: 90-374-254-1000. E-mail: aliosmansolak@ hotmail.com
}

Received: May 15, 2016

doi:10.5539/ijef.v8n8p33
Accepted: May 24, 2016

Online Published: July 25, 2016

URL: http://dx.doi.org/10.5539/ijef.v8n8p33

\begin{abstract}
The most common mode of intercity passenger transportation in Turkey is coach transport. This study focuses on regulations adopted in 2003 on scheduled intercity coach market and the consequences of these regulations, and offers several insights on the future of the sector. Due to regulations adopted and increased intermodal competition, the number of companies in the market has dropped to a certain extent. It is predicted that intermodal competition will increase further in the coming years, leading to a further decline in the number of companies, which will in turn intensify collaboration among companies. In a nutshell, the lessons to be taken from the Turkish experiment can be summarized as follows: It is possible to carry out intercity transportation unsubsidized. Having a free transportation market is key to the development of the market. Intermodal and potential competition is crucial for passenger transportation.
\end{abstract}

Keywords: Turkey, intercity coach transportation, regulation, competition

\section{Introduction}

Road transportation activities in Turkey are conducted within the framework of the Road Transportation Law (RTL) no. 4925, which entered into force on July 19, 2003, and the Road Transportation Regulation (RTR) drawn up to implement this law and entered into force on February 25, 2004. RTL and RTR, both of which were actually prepared considering the aim of adjusting with the European Union (EU) (Note 1), represented a significant turning point for the road transportation sector. Some of the regulations introduced by RTL and RTR were related with scheduled intercity passenger coach transportation (SIPCT) market. This paper addresses the economic regulations in the SIPCT market and their consequences. Since available statistics concerning this sector are insufficient, we conducted face-to-face interviews and interviews via communication tools with industry officials and directors of corporations in order to obtain more data.

The structure of the paper is as follows: The following section deals with the theoretical background and relevant literature related with cases which require government intervention; the third section describes the outlook of SIPCT industry before RTL was introduced; the fourth section discusses the regulations and their impact on competition in the sector; the fifth section presents anticipations on the future of the sector, and the final section presents and overview and the lessons to be taken from Turkey's SIPCT experience.

\section{Theoretical Background and the Relevant Literature}

According to economic theory, the cases which require government intervention are limited to market failures and the situations in which market mechanism may yield unfair outcomes in terms of the distribution of welfare. Under such circumstances, government intervention takes the form of either the production of goods and services directly by the public sector or regulations imposed on the goods and services produced by the private sector. The latter takes the form of regulations on prices and quantities, quality and performance, and entry and exit to the markets.

Government intervention in the transportation sector is usually due to the existence of natural monopolies, network industries and externalities. Besides, government intervention is relatively strong in passenger transportation industry since the market does not yield satisfactory outcomes in sociopolitical terms.

The structure of intercity coach transportation market and government intervention vary across countries. Some countries liberalized their markets a long time ago, while others exerted strict regulations to protect railways. The market was liberalized in the USA in 1980, and in the same year in Britain, which was the first country in 
Europe to liberalize its intercity coach transportation market. Swedish and Norwegian markets were liberalized in 1998 and between 1998 and 2003, respectively. In Poland, liberalization process was initated in 1990. Italian market was liberalized between 2007 and 2013, whereas German market was liberalized in 2013. Intercity coach travel is restricted in France for the sake of protecting rail transportation.

Academic studies on liberalization, regulations and the level of competition in coach travel market in different countries are rare compared to studies on other modes of transportation. However, the number of scholarly works has been currently increasing. Robbins and White (1986), and White and Robbins (2012) focused on the British market; Leiren and Fearnley (2007, 2008), and Aarhaug and Fearnley (2016) focused on the Norwegian market; Taylor and Ciechanski (2008) analyzed the Polish market; Gleave (2009) and Van de Velde (2013) evaluated the European market in general; Alexandersson et al. (2010) compared Swedish and Norwegian markets; Walter et al. (2011) focused on the German market; Beria et al. (2013, 2014) studied the Italian market; and Augustin et al. (2014) conducted a comparative study on German and US markets. These studies revealed that the impacts of market liberalization and regulations differed across countries, and while market liberalization has generally resulted in the expansion of the market, the number of companies in the market remained unchanged, leading to a consolidation of the market contrary to the intended result. In Turkey, Solak (2014) and Turkish Competition Authority (2011) conducted various studies on the regulations regarding passenger transportation by bus and on the level of competition.

\section{The Profile of the Market Before the Introduction of Road Transportation Law}

Before dealing with the outlook of coach transportation and the market structure in the pre-RTL period, it will be useful to briefly look at the market structure of other modes of transportation for comparison. In airline transportation industry, Turkish Airlines (THY) had operated as the legal monopoly until 2003. As a result of the liberalization and marketization of airline transport, the number of companies in the market and domestic flights have increased. Flight tickets, which had been very expensive before the liberalization, became much cheaper due to intensifying competition after the liberalization. In rail transportation, the Turkish State Railways (TCDD) had operated as the legal monopoly until 2013. Even though TCDD is not managed effectively, making losses for years, and subsidized by the state, no fundamental structural change had been made in rail transport until 2013. The liberalization of rail transport law was enacted in 2013; however, TCDD still operates as a monopoly. In this field, passengers had been completely carried by the conventional trains until 2009. After this date, a limited amount of high-speed trains were started to be used. Conventional train fares are cheaper than bus fares, but they are slower and the quality of services is relatively low. The railway network does not reach many of the city centers. In maritime transportation, in turn, the available transportation lines are very limited due to Turkey's geographic conditions. Most of these lines are managed by the municipalities.

Approximately \%35-45 intercity passenger transport services in Turkey are carried out by buses (TCDD, 2015). A significant part of coach transportation services is managed by transportation companies through scheduled services (Note 2). Coach transportation has a network structure that reaches to all urban centers. Ankara has become a natural hub for the center and eastern regions of the country, while İstanbul has become the natural hub for western regions. Passengers are transported to almost all cities from these hubs. The most important and dense transportation line is Ankara-İstanbul, and the number of companies which serve in this line is very high. Generally, the elderly, students and low-income groups who cannot afford to buy a car prefer coach transportation. The General Directorate of Road Transport Regulation (GDRTR) regulates and supervises all passenger and freight transport including coach transportation. GDRTR monitors transportation activities on highways through 13 Regional Directorates spread out to the whole country.

Since its early development, scheduled intercity coach transportation services has been rendered by private companies, without receiving any government incentives or without being subject to arduous regulations, under free market conditions. The sectoral regulations before RTL did not stipulate any entry barriers the market and companies which had an authorization certificate had opportunity to employ numerous contracted vehicles. There was no considerable government intervention on prices, lines and routes, schedules and headways. The regulatory body had always approved the price tariffs and timetables of companies without making revisions.

Since the transportation market has expanded in years, the number of companies and buses in the sector has increased. Companies which received authorization certificate preferred to use contracted buses instead of using their own buses since they had the permission to use a limitless amount of contracted buses. Companies acquired commissions from contracted carriers which served under their business titles. In other words, companies acted as umbrella organizations of individual bus owners. Even individuals who own a single bus was able to enter the market by signing contracts with companies that hold an authorization certificate. Coach ownership was 
regarded as an investment safeguarded from high inflation rates in this period, and individuals who had the necessary financial resources allowed companies to employ the buses they purchased for investment purposes through contracts. Companies had employed contracted buses usually in lines and services where the passenger density is low, and kept receiving commissions for each passenger even when the seat occupancy rates were low. Although this practice yielded profits for companies, bus owners suffered losses, which led to constant purchase and sale of buses. The situation was further aggravated due to the fact that bus owners were generally uneducated people, who estimated costs and profits only on the basis of fuel costs while ignoring depreciation, vehicle maintanence and inflation charges.

Since entry to the market was free and companies were allowed to use contracted buses limitlessly, a considerable excess supply built up in the market, and the number of companies and buses exceeded the necessary amounts (Note 3). There were 461 companies operating in the sector in total before the introduction of the mentioned regulations (GDRTR, 2016). Most of these were small and uninstitutionalized companies rendering services at regional level. The multitude of companies, most of which were rendering regional services had reduced occupancy rates and efficiency. Since there are insufficient statistics about the sector, it is impossible to present this case in figures. However, the fact that carriers are serving with very low occupancy rates except religious holidays, Christmas and the Hajj season, was expressed by the representatives of sector and relevant public officers in several cases (Aydın, 2011; SPO, 2006; Erdoğan, 2011; ITU, 2005). The low occupancy rates in the sector have sometimes led to predatory price wars between companies in the absence of price floors (ITU, 2005; Ministry of Transportation, 2009). Companies which served in the same transportation lines were engaged in the predatory price wars to take others out of the market and thus prevented the formation of a healthy competitive environment. This feature was also expressed in the decisions of the Competition Authority (Note 4). The severest damages due to inefficient transportation practices were inflicted upon bus owners, as already mentioned.

When we look at the pre-RTL period in terms of competition, it is possible to say that the level of competition was high in general due to the vast number of companies in the market and the absence of any barrier to market entry. This was reflected on prices as well. Although monopoly prices were occasionally imposed on some lines where only a few companies operated, prices generally reflected a highly competitive market structure. However, the competitive structure which had emerged as a result of the presence of vast number of companies did not increase companies' efficiency, but rather led to various inefficient outcomes. This was a result of the sector's network structure, where the economy of scope and concentration had a significant role (OECD, 2001).

\section{Regulations and Their Impact on the Level of Competition in the Market}

\subsection{Entry Regulations and Their Impacts}

Companies must meet three fundamental criteria -financial capability, professional competency and professional reputation- to enter the road passenger transportation market in the European Union (Note 5). These three fundamental criteria were taken into account in Turkey and the entry regulations were prepared based on them (Note 6). Companies which are eager to function in scheduled intercity passenger transportation in Turkey have to acquire the certificate of authority called D1. In order to get D1 certificate of authority, companies have to have a total coach capacity of at least 150 seats and business capital of 60,000 TL (US\$20,979). The cost of the certificate of authority is 61,372 TL (US $\$ 21,459$ ) as of 2016 and it has to be renewed in every five years. The renewal price is $15 \%$ of the initial price. These regulations are valid for initial entry to the market, but they are not required either to conduct transportation activities in the new lines or to transfer one's own activities from a line to another. Any person who holds a D1 certificate of authority is allowed to use contracted vehicles provided that the number of contracted vehicles do not exceed twice the number of self-owned vehicles and 1 transprtation line can be granted to approximately 50 self-owned seats. It is expressed in the regulations that limitations and/or temporary regulations may be imposed on the issuance and/or number of the certificates of authority, the number and/or capacities of vehicles, transportation lines and/or routes. But, no restriction has been imposed so far. The applications submitted by companies to get new lines are finalized by GDRTR in a short time without taking into account the amount of demands in the relevant line.

The main aims of these regulations were to curtail the number of individual bus owners who served under companies, to enhance the efficiency and institutional capacity of companies, and to consolidate the market by reducing idle capacity (Ministry of Transportation, 2007).

The imposed regulations and practices do not prescribe any direct barrier to entry into the general transportation market and to transferring from one transportation line to another. Therefore, it is possible for a new agent to render services in lines offering windfall profits, and for agents who used to serve in other lines to transfer to 
such profitable lines. However, a situation in which companies gain windfall profits is not sustainable due to risks of potential competition. Although it is true that price to acquiring a certificate of authority, the required seat capacity and business capital may constitute an indirect entry barrier by increasing the entry costs for new companies, this is not a considerable barrier in terms of reducing potential competition (Note 7).

It has been more than a decade since these regulations were put into effect, and they exerted significant impacts on the market. The entry regulations, particularly restrictions on the amount of contracted buses, have led to a considerable decline in the number of companies operating in the sector. After the regulations were carried into effect, the number of companies fell from 461 to 352 in 2016. Currently, the number of registered buses to these companies is 8,164 in total, 3,865 of which are contracted vehicles. The ratio of the contracted buses is $47 \%$. Since the available statistics on occupancy rates are insufficient, the impacts of regulations could not be demonstrated in this respect.

Besides the effects of regulation, the increase in the use of automobiles and airline transport has an effect on the decline of the number of companies in the market as discussed in the following section. In the face of increasing intermodal competition, companies in the market got consolidated in order to reduce costs, and various companies which could not keep up with intense competition have left the market.

Despite consolidation in the market, there was no monopoly pricing due to the pressure exerted by intermodal competition and potential competition risks (Note 8). In fact, GDRTR have not set any price ceiling until today since it has not been concerned with excessive prices. Similar conditions had been observed in the coach transport services in some other countries. For example, although the market was consolidated and cooperations between companies emerged in Norway, there were no monopoly prices due to potential competition risks (Leiren \& Fearnley, 2008).

\subsection{Price Regulations and Their Impacts}

The regulations regarding the sector stipulate that price floors and/or ceilings may be imposed for a specified period in the event that market prices act to the detriment of national economy and/or public interest, excessive prices are set and/or competition is disrupted. Moreover, it is mandatory for anyone who holds a certificate of authority to prepare price tariffs, which must be approved by GDRTR before being put into practice. Companies cannot exceed those tariffs and discount the prices more than $\% 30$ of the set prices.

In practice, GDRTR sets price floors regarding transportation services according to the length of lines, but it does not set price ceilings. The practice of setting price floors aims to protect economic agents from predatory price setting, which is frequently experienced. The GDRTR does not intervene in price ceilings set by companies during the approval process of price tariffs prepared by certificate of authority holders, but it solely checks whether the prices comply with price floors. Therefore, the intervention to prices in the sector is limited with the imposition of price floors. As already mentioned, the competitive pressure has kept prices within reasonable limits as perceived by consumers, which in turn rendered setting price celilings obsolete.

The price floor implementation precluded predatory pricing practices in the sector. During the interviews, sector officials stated that the number of companies which were fined for setting prices below price floors were very few. Thus, the regulations reached their aim on this account. Setting their prices very close to each other, the companies which render services on the same line gravitate towards competition in terms of service quality instead of price competition (Note 9). Companies have increased their service quality through several facilities such as selling tickets online, introducing extra comfortable, express coach services, offering in-vehicle food and beverage services, and providing intracity and airport shuttle services.

GDRTR set price ceilings for bus terminals which have some indirect impacts on the sector. This practice is related with concerns regarding terminal operators which may be engaged in price gouging owing to their monopolistic position. Since terminal prices are reflected on transportation costs, and thus on coach fares, keeping these prices at a reasonable level is to the benefit of companies and consumers.

\section{Future Prospect}

\subsection{Increasing Intermodal Competition}

In most of the developed countries, the share of coach transport has been declining while the share of other modes of transportation and automobiles have been increasing in intercity passenger transportation as a result of increasing competition between different modes of transportation (OECD, 2001). This can be observed in Turkey as well. In most transportation lines, coach transport companies are faced with the competitive pressure of other modes of transportation. Particularly, a strong competitive pressure is exerted by airline transport. After the marketization of airline transport services, transportation lines have increased and tickets have become much 
cheaper, leading to intensified competition between these two transportation modes. Furthermore, airline transport industry is subsidized by the government in order to establish a more balanced passenger transport market by increasing the share of airline transport. Airline companies are exempted from special consumption taxes levied on fuel prices. This practice is reflected on flight ticket prices. As shown in Table 1, while the share of airline transport was $1.6 \%$ in 1995, it increased to $8.5 \%$ in 2014. A considerable part of airline passengers used to prefer coach transport in the past (Erdoğan, 2011). In the forthcoming years, the share of the airline transport will further increase. Several new airports have been constructed and the construction of some others are being planned (Note 10). The airports to be built will increase the flight destinations of airline companies, hence the number of theirpassengers. Moreover, those new destinations will boost the scale of airline companies while reducing their costs. If these factors are reflected on prices, the number of passengers will increase further due to the price flexibility.

Table 1. Passenger transport by transport modes in Turkey (million)

\begin{tabular}{cccccccccc}
\hline \multirow{2}{*}{ Years } & \multicolumn{2}{c}{ Road } & \multicolumn{2}{c}{ Railroad } & \multicolumn{2}{c}{ Maritime } & Air Transport & Grand Total \\
\cline { 2 - 9 } & Passenger-km & $\%$ & Passenger-km & $\%$ & Passenger-km & $\%$ & Passenger-km & $\%$ & Passenger-km \\
\hline 1995 & 155,202 & 96.0 & 3,700 & 2.3 & 61 & 0.04 & 2,666 & 1.6 & 161,629 \\
2000 & 185,681 & 95.9 & 4,240 & 2.2 & 56 & 0.03 & 3,555 & 1.8 & 193,532 \\
2005 & 182,152 & 95.3 & 3,661 & 1.9 & 1,240 & 0.65 & 3,992 & 2.1 & 191,045 \\
2010 & 226,913 & 97.8 & 3,606 & 1.6 & 1,570 & 0.68 & - & - & 232,089 \\
2014 & 276,073 & 89.8 & 3,458 & 1.1 & 1,806 & 0.59 & 26,204 & 8.5 & 307,541 \\
\hline
\end{tabular}

Note. Urban transport is not included.

Source. TCDD 2011; TCDD 2015.

The number of private car owners has been increasing for years in Turkey. As illustrated in Figure 1, while the number of automobiles per 100 persons was 6.5 in 2000, this figure has increased to 13.4 in 2015 (TUIK, 2016). The increase in the use of automobiles has some impact on other modes of transportation; however, its biggest impact can be observed on coach transport. Figure 1 shows that the private car ownership, which has an increasing trend, does not yet reached to its point of saturation, so it will continue to increase in the coming years in parallel with growth of income. Coach transport industry will be the most adversely affected sector from this development.

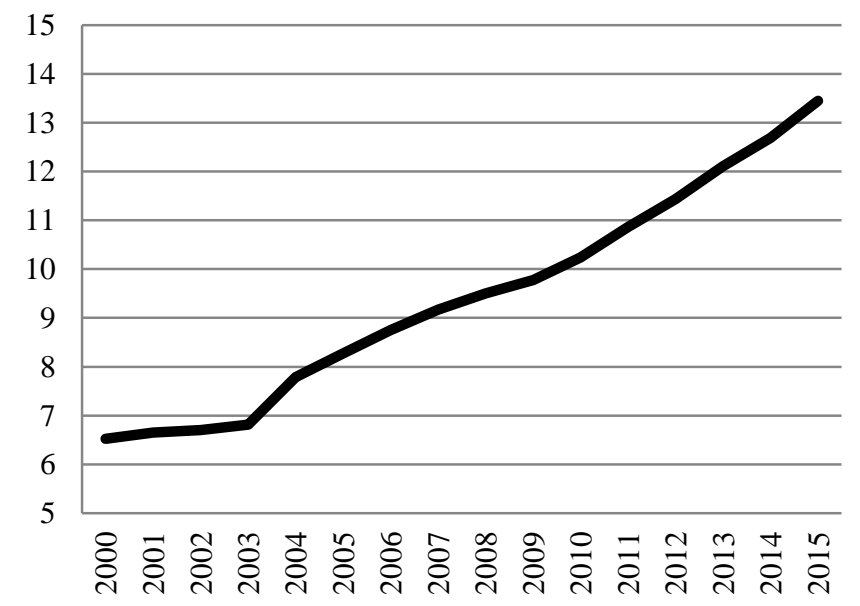

Figure 1. Number of car per 100 persons in Turkey by years

Source: Own illustration using the data published by TUIK (2016).

The share of rail transport in the total amount of the passenger transportation has declined both proportionally and numerically; while its share was $2.3 \%$ in 1995, it fell to $1.1 \%$ in 2014. However, high-speed trains, which started to render passenger transportation services in 2009 , constitute a considerable alternative to coaches. The 
length of high-speed train railway lines was $1,213 \mathrm{~km}$ by the end of 2014, and they carried nearly 1,555 million passengers in the same year (TCDD, 2015). While high-speed train fares in the available lines are slightly more expensive than coach fares, passengers prefer to travel with them as they provide relatively comfortable and faster travel opportunities. Thus, coach companies operating in the same lines were compelled to significantly curtail the number of their trips. It is true that the length of transportation lines in which the high-speed trains are carrying passengers is not too much, yet, some railway lines are still in construction and new lines are planned to be constructed (Note 11). When the transportation activities begin in those lines, coach transport will face a very strong competitive pressure which may lead to a significant market loss. It seems very difficult that conventional trains, as they stand, are suitable to be a part of intermodal competition. Yet, the liberalization of rail transport law might change this situation.

Maritime transport industry is engaged in passenger transportation at a limited extent due to the country's geography. While the share of maritime transport was almost non-existent by the end of 2000 , itincreased to $0.68 \%$ by the end of 2010, and decreased once again to $0.59 \%$ by the end of 2014 . The share of maritime transport is not expected to increase considerably in the coming years. However, there is an ongoing cut-throat competition between coach transport and maritime transport on the lines where the latter exists (such as İstanbul-Yalova).

In general, it is evident that intermodal competition has increased and will further intensify in the following years. In parallel with the increase in intermodal competition, the share of coach transport will decline proportionally although it might maintain its position in numerical terms. The most important factor which affects the intensification of intermodal competition, thus coach transport, is the per capita income. It is expected that income growth will have a negative effect on coach transport since individuals who have higher income would prefer to own a car or to travel by airplane and/or high-speed train instead of bus. On the other hand, the number of total trips increases in parallel with the increase in income, which will in turn boosts the number of trips by all modes of transportation (Gleave, 2009). Nonetheless, at the mid-range lines $(300 \mathrm{~km}-500 \mathrm{~km})$ where it is not possible to utilize high-speed train transports due to geography and there is not flight point, it can be predicted that bus transportation will increase.

\subsection{Increasing Consolidation and Collaborations}

In the past decade, the number of companies in the sector has declined and a certain degree of consolidation has occured. While the consolidation was partly due to new regulations adopted, it was also a result of intermodal competition. Companies have reduced the number of their trips on lines where intermodal competition was intense, and some companies were compelled to withdraw from such lines. In addition to consolidation, there were also new collaborations among firms which were in compliance with competition law (Note 12). For example, two companies, Pamukkale and Anadolu, have collaborated to connect their ticket offices in order to reduce their costs and increase the number of their booking offices. It can also be observed that companies which have broad service network and web infrastructure sign agreements to allow their titles to be used.

Despite the ongoing consolidation of and collaborations in the sector, increasing intermodal competition will further consolidate the market and improve collaborations, because currently the scale of most companies in the sector, which has the characteristics of a network industry, is very small, rendering regional services only. For instance, the number of cities where D1 certificate of authority holders registered in the XIII ${ }^{\text {th }}$ Regional Office of GDRTR (Bolu, Düzce, Sakarya, Zonguldak, Karabük, Bartın ve Kastamonu) render their services is presented in Table 2 below. As the Table indicates, the firm which has the broadest network among the 15 companies registered in 7 cities is S.S. Düzce Güven, which carries out its activities in 24 cities in total. Five of these companies provide services only in two cities. Given the fact that there are 81 cities in Turkey, it will be easier to grasp the scale of these companies' transportation networks. In the face of increasing intermodal competition, these small scale companies will have to capitalize on cost advantages and increase their competitivity through mergers, acquisitions and collaborations. In fact, a similar condition occured in some other countries. Collaborations between companies had become more prevalent in the Norwegian market, whereas consolidation was much more prevalent due to the cost advantages in British and Swedish markets (White \& Robbins, 2012; Leiren \& Fearnley, 2008; Alexandersson et al., 2010; Aarhaug \& Fearnley, 2016). 
Table 2. The number of cities where D1 certificate of authority holders registered in the 13th regional directorate of GDRTR render their services

\begin{tabular}{llc}
\hline Title of company & Company center & Number of cities where companies serve \\
\hline S.S. Düzce Güven & Düzce & 24 \\
Sakarya Vib & Sakarya & 20 \\
Üstün Erçelik & Zonguldak & 11 \\
Hasan Çatal & Kastamonu & 6 \\
Yenice Etap & Karabük & 5 \\
Tosya Seyahat & Kastamonu & 4 \\
Araç Doğuş & Kastamonu & 4 \\
Has Bartın & Bartın & 3 \\
Yeşil Göynük & Bolu & 3 \\
Tahir Öztürk & Bartın & 3 \\
Cide Güven & Kastamonu & 2 \\
Düzce Güven & Düzce & 2 \\
Evin Taşımacılık & Sakarya & 2 \\
Raşit Nalbant & Kastamonu & 2 \\
Sakarya Sev & Sakarya & 2 \\
\hline
\end{tabular}

Source. Solak (2014).

The possible consolidation and collaborations in the sector may be in breach of the competition law. In this regard, consolidation and collaborations contain a potential dispute in itself. In fact, similar disputes were observed in Norway and Sweden. The National Competition Authority of Sweden was not very fond of collaborations. However, the government of Norway supported collaborations due to increased intermodal competition and efficiency despite the opposition of the National Competition Authority (Alexandersson et al., 2010; Aarhaug \& Fearnley, 2016).

In Turkey, mergers, acquisitions and collaborations are contingent on certain conditions laid down by the Competition Law. At this point, the relevant market definition of the Competition Authority and its evaluations on potential competition in the market, intermodal competition and the financial structure of the market become significant. The Competition Authority has not yet made any decision regarding mergers and acquisitions in the sector; however it has reached a decision on the collaboration agreement signed between two companies, Pamukkale and Anadolu. The Competition Authority concluded that this agrement met the conditions of exemption upon the justifications that the agreement will yield in a considerable reduction in the costs of the companies, the opportunity to sell their tickets at a greater number of booking offices, and thus to reach more customers, while providing the opportunity to find tickets at more locations and at discount prices on behalf of the customers (Note 13).

\section{Conclusion and Discussion}

Coach transport is the most commonly utilized mode in intercity passenger transportation in Turkey. Starting from its early development, coach transport services have been provided by private companies without any government subsidies and under free market conditions. The number of firms and coaches operating in the sector has increased in years. However, the bulk of companies operating in the sector are small scale, uninstitutionalized enterprises, carrying out their activites at regional level. Since the sector has the caharacteristics of a network industry, the high number of companies and their activities at regional level had a negative impact on their occupancy rates and efficiencies. Therefore, the RTL and RTR introduced certain regulations to consolidate the market by reducing the idle capacity and to improve the institutionalization level of the companies.

More than a decade has passed since these regulations were put into effect. Within this time period, the number of firms has decreased in the market and a consolidation has occured to a certain degree. The number of companies fell from 461 before the adoption of RTL to 352 by 2016. Besides these regulations, intermodal competition also had an impact on the decline in the number of firms in the market. Companies were engaged in consolidations in order to get reduce their costs, which would increase their competitive strength in the face of intensifying intermodal competition, while some of the companies were compelled to leave the market as they were not able to resist this competition. Despite the consolidation in the market, there has been generally no 
monopoly price setting practices due to the intermodal competition pressure and potential competition threats.

Recent developments point to the following future trends: intermodal competition will increase further in the future. Along with the increase in intermodal competition, the share of coach transport will decline in proportional terms, though not necessarily in numerical terms. The increasing intermodal competition will further consolidate the market and improve collaborations. At this point, it is possible that consolidation and collaborations may not comply with the Competition Law.

The lessons which may be taken from the experiences of intercity scheduled passenger coach transportation in Turkey are as follows:

- It is possible to carry out the intercity transportation without government subsidization. In Turkey, passenger transportation services to all cities have been rendered without using any public funding and without the necessity to sign any public service obligation agreement for years. In this regard, coach transport has functioned and is still functioning a crucial role in connecting different regions of the country to each other and providing social mobility. On the other hand, railways are not preffered in spite of the fact that it is run under a legal monopoly and subsidized by government for many years.

- Having a free transport market is significant in terms of market development. The maintanence of free market structure in transportation activities has a considerable impact on the fact that coach transport is the most preferred mode of transportation. The competitive market structure also plays a positive role on issues such as flexibility, use new technologies, service quality, and costs. As a matter of fact, airline transport services have also developed considerably, and increased its market share, enhanced its service quality and reduced its prices as a result of marketization.

- Intermodal competition and potential competition are important factors in passenger transportation. It is necessary to take such features into account while reflecting on the transportation market in terms of competition. A decline in the number of companies in any transportation line does not necessarily lead to the emergence of monopolistic trends. The presence of intermodal competition and potential competition also affect the behaviors of companies.

\section{References}

Aarhaug, J., \& Fearnley N. (2016). Deregulation of the Norwegian long distance express coach market. Transport Policy, 46, 1-6. http://dx.doi.org/10.1016/j.tranpol.2015.11.004

Alexandersson, G., Hultén, S., Fearnley, N., \& Longva, F. (2010). Impact of regulation on the performances of long-distance transport services: A comparison of the different approaches in Sweden and Norway. Research in Transportation Economics, 29, 212-218. http://dx.doi.org/10.1016/j.retrec.2010.07.026

Augustin, K., Gerike, R., Sanchez, M. J. M., \& Ayala, C. (2014). Analysis of intercity bus markets on long distances in an established and a young market: The example of the US and Germany. Research in Transportation Economics, 48, 245-254. http://dx.doi.org/10.1016/j.retrec.2014.09.047

Aydın, T. (2011). Kara ulaştırması ve karayolları. In R. Kurumu (Ed.), Ulaştırma sektöründe serbestleştirme, rekabet ve rekabet hukuku sempozyumu kitabı içinde (pp. 47-69). (Originally in Turkish).

Beria, P., Grimaldi, R., \& Laurino, A. (2013). Long distance coach transport in Italy: State of the art and perspectives. MPRA Paper No. 53768, University Library of Munich, Germany.

Beria, P., Grimaldi, R., Debernardi, A., Ferrara, E., \& Laurino, A. (2014). Spatial and scenario analyses of long distance coach transport in Italy. MPRA Paper No. 54739, University Library of Munich, Germany.

Erdoğan, M. (2011). Kara ulaştırması ve karayolları. In R. Kurumu (Ed.), Ulaştırma sektöründe serbestleştirme, rekabet ve rekabet hukuku sempozyumu kitabı içinde (pp. 71-74). (Originally in Turkish).

GDRTR (General Directorate of Road Transport Regulation). (2016). Retrieved from http://www.kugm.gov.tr

Gleave, S. D. (2009). Study of passenger transport by coach, Final Report. Prepared for European Commission Directorate General Energy and Transport.

ITU (Istanbul Technical University). (2005). Ulaştırma ana planı stratejisi sonuç raporu. İstanbul (Originally in Turkish).

Leiren, M. D., \& Fearnley, N. (2007). Public funding to long distance buses: An entry barrier or a necessity? Paper presented at the 10th International Conference Series on Competition and Ownership in Land Passenger Transport (Thredbo 10), Hamilton Island, Queensland, Australia. 
Leiren, M. D., \& Fearnley, N. (2008). Express coaches - the story behind a public transport success. Paper presented at the 2008 European Transport Conference in Leeuwenhorst Conference Centre, The Netherlands.

Ministry of Transportation. (2007). Ulaşımdan iletişime kalkınan Türkiye 2003-2007. Ankara (Originally in Turkish).

Ministry of Transportation. (2009). Ulaştırma Bakanlığl stratejik planı 2009-2013. Ankara (Originally in Turkish).

Ministry of Transportation. (2016). İdare faaliyet raporu 2015. Ankara (Originally in Turkish).

OECD. (2001). Competition issues in road transport. Paris.

Robbins, D. K., \& White, P. R. (1986). The experience of express coach deregulation in Great Britain. Transportation, 13(4), 359-384. http://dx.doi.org/10.1007/BF00215254

Solak, A. O. (2014). Türkiye otobüs ile şehirlerarası tarifeli yolcu taşımacıllğı sektörünün rekabet düzeyi. Rekabet Dergisi, 15(4), 40-77.

SPO (State Planning Organization). (2006). Kalkınma planı - karayolu ulaşımı özel ihtisas komisyonu raporu. Ankara, (Originally in Turkish).

Svorny, S. (2000). Licensing, market entry regulation. In B. Bouckaert, \& G. De Geest (Eds.), Encyclopedia of Law and Economics Volume III (pp. 296-328). Edward Elgar, Cheltenham, UK.

Taylor, Z., \& Ciechański, A. (2008). What happened to the national road carrier in a post-communist country? The Case of Poland's State Road Transport. Transport Reviews, 28(5), 619-640. http://dx.doi.org/10.1080/01441640801943018

TCDD (Turkish State Railways). (2011). Annual statistics 2006-2010. Ankara.

TCDD. (2015). Annual statistics 2010-2014. Ankara.

TUIK (Turkish Statistical Institute). (2016). Retrieved from http://www.tuik.gov.tr

Turkish Competition Authority. (2011). Ulaştırma sektöründe serbestleştirme, rekabet ve rekabet hukuku sempozyumu kitabı. Ankara, (Originally in Turkish).

Van de Velde, D. (2013). Long-distance coach services in Europe. In M. Finger, \& T. Holvad (Eds.), Regulating transport in Europe (pp. 115-139). Edward Elgar, Cheltenham, UK. http://dx.doi.org/10.4337/9781781004838.00010

Walter, M., Haunerland, F., \& Moll, R. (2011). Heavily regulated, but promising prospects: Entry in the German Express Coach Market. Transport Policy, 18(2), 373-381. http://dx.doi.org/10.1016/j.tranpol.2010.11.001

White, P., \& Robbins, D. (2012). Long-term development of express coach services in Britain. Research in Transportation Economics, 36, 30-38. http://dx.doi.org/10.1016/j.retrec.2012.03.012

\section{Notes}

Note 1. Having started accession negotiations with the EU on October 3, 2005, Turkey has been seeking to revise her regulations to comply with EU acquis.

Note 2. There is no data on scheduled and unscheduled services. But during the interviews, industry officials stated that more than half of total coach transport was carried out through scheduled services.

Note 3. In the buildup of excess supply, the absence of sunk cost risk was also effective. SIPCT sector does not require a considerable amount of fixed investment except the cost of buying buses. Companies have the chance to sell buses at a good price in the second hand market.

Note 4. See Competition Authority Decision No. 10-68/1445-545 of 28.10.2010, and Decision No. 09-27/576-136 of 11.06.2009.

Note 5. See. Council Directive 96/26/EC, and Council Directive 98/76/EC.

Note 6. Financial capability refers to having the necessary financial sources to establish an enterprise engaged in transportation activities, to manage such company efficiently and to run it properly; professional reputation refers to acting in accordance with the codes of conduct of commerce and to comply with the rules related with road transportation activities; and professional competency refers to having the education, knowledge, skill and 
equipment required for carrying out the road transportation activities.

Note 7. The direct entry barrier refers to restriction on the number of companies which serve in the market in general or in a specific transportation line. The indirect entry barrier, however, refers to increased entry costs to the market by legal means (Svorny, 2000).

Note 8. Although the competition level is high in the sector, Competition Authority issued 7 administrative fines and 8 warnings on the grounds of violation of article 4 of the LawNo. 4054 on the Protection of Competition, which regulates the fines to be imposed in the event of price setting, market sharing and supply setting practices (Solak, 2014).

Note 9. "Mutual dependency" in the oligopolistic markets can be observed in the SIPCT sector, too. Companies which render services on the same lines fail to set their prices independently from their rivals, hence prices become very close to each other as if companies have agreed on them.

Note 10. For airport investments which are still being constructed and are planned to be built in the following years, see Ministry of Transportation (2016).

Note 11. For high-speed train projects which in construction and are planned to be built in the following years, see Ministry of Transportation (2016).

Note 12. Collaborations have a series of clear advantages such asthe integration of services, marketing, greater bargaining power in the transactions with tourism agencies or employee education (Alexandersson et al., 2010).

Note 13. See The decision no. 12-42/1264-415 and date 28.08.2012 reached out by the Competition Authority.

\section{Copyrights}

Copyright for this article is retained by the author(s), with first publication rights granted to the journal.

This is an open-access article distributed under the terms and conditions of the Creative Commons Attribution license (http://creativecommons.org/licenses/by/3.0/). 